\title{
Extending Shelf Life of Peeled Shrimp Using Moringa oleifera and Isoflavones
}

\author{
Gahad Sallah Saeed Eldeeb $^{1^{*}}$ and Sameh Hassan Mosilhey ${ }^{2}$ \\ ${ }^{1}$ Department of Food Technology, Faculty of Agriculture, Suez Canal University, Ismailia, Egypt, 41522 \\ ${ }^{2}$ Department of Food, Dairy Sciences and Technology, Faculty of Environmental Agricultural Sciences, Arish \\ University, North Sinai, Egypt
}

Received: $23 / 2 / 2021$

\begin{abstract}
The current study was carried out to evaluate the shelf life of peeled shrimp during ice storage for 14 days using $125 \mu \mathrm{g} / \mathrm{ml}$ of crude isoflavones extract (CIE), $250 \mu \mathrm{g} / \mathrm{ml}$ of crude moringa extract (CME) and a mixture of both $(62 \mu \mathrm{g} / \mathrm{ml} \mathrm{CIE}$ and $25 \mu \mathrm{g} / \mathrm{ml} \mathrm{CME})$, as an antioxidant and antimicrobial agent. The results showed that using CME and/or CIE in ice improved the quality of peeled shrimp during ice storage. All treated samples showed; low content of total volatile nitrogen (TVN), trimethylamine (TMA), Thiobarbituric acid (TBA), cooking loss and free amino acids compared to the control sample, while the water holding capacity (WHC) of treated samples was increased. CME and/or CIE had a greater effect on spoilage microorganisms in treated samples of peeled shrimp, whereas the control sample reached the spoilage onset $\left(10^{7} \log \mathrm{CFU} / \mathrm{g}\right)$ after eight days. In comparison, the treatment with $\mathrm{CME}$ and/or CIE additives prolonged the samples' shelf life to 14 days. Total bacterial count, Pseudomonas sp., Aeromonas sp. and Enterobactereace can be inactivated by CME or CIE. Significant differences were observed in mean sensory scores between treatments and control. The control recorded the lowest scores, while higher scores were obtained from the sample treated by CME plus CIE.
\end{abstract}

Keywords: Antioxidant, antimicrobial, free amino acids, cooking loss, sensory scores

\section{INTRODUCTION}

Nowadays, consumers became more aware of the relationship between their health and the food they eat. Natural plant additives and their antibacterial activity against food spoilage and pathogenic microorganisms are noticeable with the synthetic ones. Food spoilage is determined by physicochemical, microbiological and sensory changes, making it harmful and unsuitable for consumption (Kuswandi et al., 2012).

Shrimp is an important type of seafood consumed on a worldwide scale. They are high in protein, iodine, calcium and low in food energy (low in total fat). Consumption of shrimp is considered a healthy diet for our circulatory system due to its low saturated fat contentand omega-3 highly unsaturated fatty acids. Thus, its high cholesterol content improves the LDL to HDL cholesterol ratio and triglycerides reduction (Ouraji et al., 2009).

On the other hand, about $15 \%$ of outbreaks for humans are attributed to fish consumption (Pilet and Leroi, 2011). Shrimp quality and acceptability for consumption are essentially linked to its freshness, mainly determined by microbial, physical, biochemical and sensory parameters (Kuswandi et al., 2012). The most of seafood products spoilage is caused by microorganisms giving the associated off-flavors. Shrimp spoilage as loss of texture, discoloration and foul odor is attributed to the microorganisms and its proteolytic enzymes and the autoxidation of unsaturated fatty acids (Bazemore et al., 2003).

Ice storage alone is insufficient to preserve and keep shrimp quality after the catch, during handling and post-harvest. Therefore, adding natural preservatives could retard spoilage and enhance shelf life. Flavonoids, a group of natural products with variable phenolic structures, are well known for their beneficial health effects. Moreover, this is attributed to their anti-carcinogenic, anti-inflammatory and antioxidative (Panche et al., 2016). Isoflavonoids are a subclass of flavonoid phenolic compounds from a wide plant variety, which are active biologically. Isoflavonoids and their compounds related have been applied to many dietary supplements, antioxidant and antibacterial (Olasupo et al., 2018).

Moringa leaves provide vitamin $\mathrm{C}$ higher than in orange ( 7 times), higher in vitamin A than carrots (10 times), higher calcium content than milk (17 times), higher protein than yogurt (9 times), higher potassium than bananas (15 times) and higher iron than spinach (25 times). It can be called the tree of life and multipurpose consumption. Its medical and therapeutic properties, due to the high phytochemical contents such as sterols, tannins, flavonoids, terpenoids, anthraquinones and saponins, can reduce sugars and alkaloids. It can work as an antioxidant, antibacterial, antifungal, cholesterol-lowering, and diuretic activity (Abdulkadir et al., 2018). Moringa oleifera extract showed antimicrobial activity against pathogenic bacteria, including Bacillus sp., Pseudomonas aeruginosa, E. coli and Staphylococcus aureus, due to the presence of phytochemicals compounds (Rajamanickam and Sudha, 2013). The main target of the current study is to find suitable sources that can provide reasonable amounts of natural biopreservatives to be used on a wide scale in the field of the food industry, such as crude moringa extract (CME) and crude isoflavones extract (CIE) from soybean, and study the effect of CIE, CME and CIE plus CME on the quality of peeled shrimp during storage in crushed ice.

This study investigates the freshness and spoilage stage by using determined chemical and microbial changes in the shrimp's flesh during icing storage and linking them with sensory changes that influence consumers' preferences for shrimp products using these results to guide in processing. 


\section{MATERIALS AND METHODS}

\section{Collecting Samples}

Soybean (Glycine max) was obtained from the Agriculture Research Centre, Giza, Egypt, during season 2018. Moringa leaves (Moringa oleifera) were purchased from a local herb shop (Ismailia, Egypt). Shrimp (Penaeus latisclcalus, 40 shrimp per kg) were brought fresh in crushed ice from a local market at Ismailia governorate and were then transported to the laboratory.

\section{Preparation of moringa extract}

Plant material (Moringa oleifera) was used to prepare crude moringa extracts (CME) containing the polar active compounds as follows; Dry moringa leaves powder $(25 \%, \mathrm{w} / \mathrm{v})$ were macerated in distilled water for seven days with occasional shaking (10 times/day). The extracts were filtered through eight layers of muslin cloth and concentrated at $40^{\circ} \mathrm{C}$ under reduced pressure. The filtrate was subjected to antimicrobial testing by minimum inhibitory concentration (MIC) and kept at $4{ }^{\circ} \mathrm{C}$ until used.

\section{Preparation of crude isoflavones extract from soybean (CIE)}

CIE from soybean was prepared as follows: Soybean seeds were milled for 3 minutes at a medium speed in a coffee bean blender. Then, the particles of the ground whole soy flour passed through a $1 \mathrm{~mm}$ sieve. Defatted soy flour $(100 \mathrm{~g})$ was weighed then transferred to a round bottom flask, then $400 \mathrm{ml}$ of distilled water was added to it at ratio 1:4 (weight: volume, soy flour: water) incubated at $45^{\circ} \mathrm{C}$ for $5 \mathrm{hrs}$. The mixture was transferred to high-speed centrifuge at $5000 \mathrm{rpm}$ for $30 \mathrm{~min}$ at $20^{\circ} \mathrm{C}$. The clarified solution was transferred to a $2 \mathrm{~L}$ round bottom flask to be concentrated under vacuum using a rotary evaporator until almost reaching the volume of $100 \mathrm{ml}$ of concentrated soybean extract. The extract obtained was subjected to antimicrobial testing by (MIC) and were kept at $4^{\circ} \mathrm{C}$ until using it.

\section{Preparation of crushed ice}

Crushed ice made from clean water mixed with CIE or CME was then kept at $-20^{\circ} \mathrm{C}$ until used.

\section{Preparation of shrimp samples}

Beheaded and shell-less shrimp flesh were divided into four groups and treated as follows:

(1) Control samples (covered with crushed ice).

(2) The second shrimp group was covered with ice made from water mixed with $\mathrm{CME}, 50 \mu \mathrm{g} / \mathrm{ml}$ (MIC).

(3) The third group was covered with ice made from water mixed with $\mathrm{CIE}, 125 \mu \mathrm{g} / \mathrm{ml}$ (as MIC). The data not recorded.

(4) The fourth group was covered with ice made from water mixed with $50 \mathrm{ml} / \mathrm{L} \mathrm{CME}$ and $62 \mu \mathrm{g} / \mathrm{ml} \mathrm{CIE}$ $(\mathrm{v} / \mathrm{v})$.

\section{Physiochemical properties} $\mathrm{pH}$, protein, fat and moisture were determined according to the methods reported by AOAC (2005).

\section{Free amino acids determination}

Free amino acids were determined using HPLC (LC 3000 Eppendorf Germany) according to the method described by Cervantes et al. (2006) as follows:

\section{Sample preparation:}

$10 \mathrm{~g}$ of shrimp mixed with $40 \mathrm{ml}$ of methanol $(75 \%)$ and blended for $2 \mathrm{~min}$. The extract was transferred quantitatively to a volumetric flask $(100 \mathrm{ml})$, completed the volume up to $100 \mathrm{ml}$ by the solvent and stored at $4{ }^{\circ} \mathrm{C}$ overnight. The extract was centrifuged at $15000 \mathrm{rpm}$ for $40 \mathrm{~min}$, and the supernatant was filtered using a filter membrane $(0.2 \mu)$ then stored at $-20^{\circ} \mathrm{C}$.

\section{OPA-thiol reagent preparation:}

OPA reagent was made by dissolving $27 \mathrm{mg} \mathrm{O}$ Phthalaldehyde in $500 \mathrm{ml}$ absolute alcohol. $5 \mathrm{ml}$ of sodium tetraborate $(0.1 \mu)$ at $\mathrm{pH} 9.5$ was added, followed by $50 \mu 1$ mercaptoethanol, and then stored in a closed container in the dark (the reagent was made up at least $24 \mathrm{hrs}$ before use).

\section{Amino acid derivatization:}

Added $400 \mu 1$ of OPA reagent to $100 \mu 1$ of diluted supernatant or standard of amino acids and mixed them thoroughly using a vortex. The sample was injected after $2 \mathrm{~min}$ of mixing. Sodium phosphate buffer (0.05M, pH 5.5) was used for the blank and the standard and diluted supernatants' preparation.

Determination of total volatile nitrogen (TVN), trimethylamine (TMA):

About $100 \pm 0.5 \mathrm{~g}$ of shrimp flesh sample was placed in a blender with $300 \mathrm{ml}$ trichloracetic acid (TCA) (5\%) until obtaining uniform slurry. The resulting slurry was centrifuged at $5000 \mathrm{rpm}$ to obtain a clear extract. Exactly $5 \mathrm{ml}$ of the extract was pipetted into a semi-micro distillation apparatus (UDK, 130A) and $5 \mathrm{ml}$ of $\mathrm{NaOH}(2 \mathrm{~N})$ was added. The final steamed distillate was collected in $15 \mathrm{ml}$ of standard hydrochloric acid $(0.01 \mathrm{~N})$. Rosalic acid was added to the solution as an indicator (1percent rosalic acid in 10 percent $\mathrm{v} / \mathrm{v}$ ethanol) and the access of acidity was titrated to a pale pink endpoint with sodium hydroxide. The amount of TVN was expressed as mg/100g. Formaldehyde (16\%) was added to the solution (1:10 $\mathrm{v} / \mathrm{v})$ to block the primary and secondary amines, and the released acid from these reactions was titrated to a pale pink endpoint with $0.01 \mathrm{~N}$ sodium hydroxide. The amount of TVN and TMA was expressed as $\mathrm{mg} / 100 \mathrm{~g}$ (Pearson 1981).

Determination of Thiobarbituric acid value (TBA)

Lipid oxidation was measured by the 2thiobarbituric acid distillation method (Pearson 1981); $10 \mathrm{~g}$ representative sample of shrimp flesh was macerated with $50 \mathrm{ml}$ water for $2 \mathrm{~min}$ and washed into a distillation flask with $47.5 \mathrm{ml}$ water. Then $2.5 \mathrm{ml}$ of $4 \mathrm{M}$ hydrochloric acid was added to bring the $\mathrm{pH}$ to 1.5 , followed by antifoaming preparation and a few glass beads. The flask was heated utilizing an electric mantle so that $50 \mathrm{ml}$ of distillate is collected in $10 \mathrm{~min}$ from boiling commences. $5 \mathrm{ml}$ distillate was pipetted into a glass-stoppered tube, $5 \mathrm{ml}$ TBA reagent $(0.2883 \mathrm{~g} / 100$ $\mathrm{ml}$ of $90 \%$ glacial acetic acid), was added followed by heat in boiling water for $35 \mathrm{~min}$. A blank was prepared similarly using $5 \mathrm{ml}$ of water with $5 \mathrm{ml}$ reagent. The tubes were then cooled in water for $10 \mathrm{~min}$, and the absorbance (D) was measured against the blank at 538 nm using $1 \mathrm{~cm}$ cells.

TBA value (as mg malonaldehyde per $\mathrm{kg}$ sample) $=7.8 \mathrm{D}$ 


\section{Determination of water holding capacity (WHC):}

WHC was determined according to the method described by (Salvador et al. 2009). Cooking loss of shrimp was determined through weighting the shrimp before and after treatment in boiling water for $3 \mathrm{~min}$.

\section{Bacteriological examinations}

\section{Preparation of the sample}

Ten grams of shrimp flesh samples were transferred to a sterile blender jar containing $90 \mathrm{ml}$ of sterile $1 \%$ peptone water. The contents were homogenized for $2 \mathrm{~min}$ at $4000 \mathrm{rpm}$ and the mixture was allowed to stand for $5 \mathrm{~min}$ at room temperature. One $\mathrm{ml}$ of the homogenate was transferred into separate tubes containing peptone water $(9 \mathrm{ml}$ each), from which 10-fold serial dilutions up to 10-6 were prepared and subjected to plating on nutrient agar, Aeromonas isolation agar, Pseudomonas isolation agar and violet red bile agar for total plate count (TPC), Aeromonas sp., Pseudomonas sp. and Enterobacteriaceae, respectively. The bacterial colonies were counted $(\log \mathrm{CFU} / \mathrm{g})$ after 24 to $48 \mathrm{~h}$ at $37^{\circ} \mathrm{C}$.

\section{Sensory evaluation}

Fifteen untrained panels assessed sensory evaluation for odor, color, texture and appearance on a seven-point hedonic scale; 1 represented attributes disliked, 3 represented attributes unacceptable and 7 represented most liked: An average of three shrimp per treatment were used for evaluation per day.

\section{Statistical analysis}

All measurement was done in triplicate and data were reported as means \pm standard deviation (SD). The analysis of variance and significant differences were tested by one-way ANOVA using SPSS software (version 16.0 for windows, SPSS Inc., Chicago). It was considered that $\mathrm{p} \leq 0.05$ was statistically significant.

\section{RESULTS AND DISCUSSIONS}

\section{Physiochemical properties}

The cooking loss yield related to control and different treatments were determined at zero time and after 14 days of storage (Table 1). The effect of treatments was measured in terms of cooking yield loss. The treated ice with (CME plus CIE) was found more effective in yield loss reduction followed by CME and CIE, respectively, compared with the control. The data showed that after 14 days of ice storage, all treatments decreased the cooking loss pronouncedly due to boiling; it is previously known that both CME or CIE had an antimicrobial effect that decreases the activity of spoilage bacteria and decreases of cooking loss due to increasing WHC and shelf life of shrimp samples. Cooking loss reduction is essential as promoting higher tenderization due to increasing the WHC. Cooking plays a vital process role in achieving safe product and palatability, essential for tenderness, flavor and hygienic quality and inactivates pathogens (Pietrasik et al., 2005). The water content affects not only the shrimp's physical and sensory properties but also the activity of spoilage bacteria and autolytic enzymes. According to Yang et al. (2017), chilling and freezing storage had a negative effect on the structure of proteins, as well as it could cause a deterioration of functional properties such as WHC. Therefore, moisture, cooking loss, and WHC were determined to evaluate peeled shrimp quality during ice storage. Data presented in Table (1) showed that WHC of shrimp samples treated with CIE, CME or a mixture of both had high values of WHC ranged from 82.51 to $87.32 \%$ when compared with control samples $(79.21 \%)$ at zero time. This comparison indicates that both CIE and CME increase the WHC of peeled shrimp. The data also showed significant differences among all treatments; the highest value appeared in treatment D (CME plus CIE). At the end of the storage period, the additives' effect did not differ from that observed at zero-time storage. Moreover, during storage, some loss of WHC occurred, possibly due to the association of some lipids oxidation products with protein, which decreased somehow its solubility accordingly, WHC (TBA value, Fig. 1). Decrease of protein capacity's ability to holding water may be attributed to the deterioration of protein by microbial activity.

Table (1): Physiochemical properties of peeled shrimp samples during ice storage (Mean \pm S.D)

\begin{tabular}{cccccc}
\hline Properties & Cooking Loss & WHC g/100g & Moisture g/100g & Protein & Fat \\
\hline Treatment & & At Zero Time & & & \\
\hline A & $27.28^{\mathrm{a}} \pm 0.008$ & $79.21^{\mathrm{d}} \pm 0.111$ & $74.11^{\mathrm{c}} \pm 0.116$ & $22.15^{\mathrm{c}} \pm 0.008$ & $1.01^{\mathrm{b}} \pm 0.082$ \\
B & $20.32^{\mathrm{b}} \pm 0.113$ & $82.51^{\mathrm{c}} \pm 0.001$ & $76.35^{\mathrm{b}} \pm 0.316$ & $22.46^{\mathrm{b}} \pm 0.033$ & $0.93^{\mathrm{a}} \pm 0.009$ \\
C & $19.81^{\mathrm{b}} \pm 0.001$ & $84.18^{\mathrm{b}} \pm 0.001$ & $76.89^{\mathrm{b}} \pm 0.008$ & $22.52^{\mathrm{a}} \pm 0.011$ & $0.92^{\mathrm{a}} \pm 0.221$ \\
D & $17.35^{\mathrm{c}} \pm 0.016$ & $87.32^{\mathrm{a}} \pm 0.119$ & $77.01^{\mathrm{a}} \pm 0.001$ & $22.38^{\mathrm{a}} \pm 0.316$ & $0.87^{\mathrm{a}} \pm 0.196$ \\
Treatment & & After 14 days & & & \\
A & $38.11^{\mathrm{a}} \pm 0.019$ & $58.89^{\mathrm{c}} \pm 0.315$ & $75.21^{\mathrm{b}} \pm 0.116$ & $20.16^{\mathrm{b}} \pm 0.321$ & $0.98^{\mathrm{c}} \pm 0.311$ \\
B & $22.31^{\mathrm{b}} \pm 0.033$ & $77.32^{\mathrm{b}} \pm 0.137$ & $77.16^{\mathrm{c}} \pm 0.001$ & $21.82^{\mathrm{c}} \pm 0.003$ & $0.89^{\mathrm{b}} \pm 0.116$ \\
C & $21.95^{\mathrm{b}} \pm 0.061$ & $78.85^{\mathrm{b}} \pm 0.111$ & $77.65^{\mathrm{c}} \pm 0.003$ & $21.88^{\mathrm{b}} \pm 0.019$ & $0.84^{\mathrm{b}} \pm 0.302$ \\
D & $19.15^{\mathrm{c}} \pm 0.009$ & $79.91^{\mathrm{a}} \pm 0.131$ & $78.12^{\mathrm{a}} \pm 0.101$ & $21.99^{\mathrm{a}} \pm 0.016$ & $0.81^{\mathrm{a}} \pm 0.113$ \\
\hline
\end{tabular}

A: Control samples,B: Shrimp samples treated with (CIE), C: Shrimp samples treated with (CME), D: Shrimp samples treated with (CME+ CIE).

Mean with different letter in the same column indicate significant differences between treatments $(\mathrm{p} \leq 0.05)$

Total phenolic compounds (TPC) of moringa oleifera leaves $51.08 \%$ and $41.11 \%$ in soybean.

Antioxidant activity (DPPH) of moringa oleifera leaves $(86.31 \%)$ and $(77.09 \%)$ for soybean. 
Simultaneously, the data showed that the initial moisture values at zero time were 74.11, 76.35, 76.89 and 77.01 for control, CIE, CME and CME plus CIE, respectively. At the end of 14 days of storage, the moisture content slightly increased to 75.21, 77.16, 77.65 and 78.12 for control, CME, CIE and CME plus CIE, respectively. Moisture content indicates the muscle's ability for water retaining, which reflects the breakdown degree of protein, and moisture increased as well as the days of storage. These results are agreed with Akintola and Bakare (2013), as mentioned, increase moisture with direct ice contact of prawn at the 10th day of storage. After 14 days of ice storage, the highest moisture content was obtained by $\mathrm{CME}$ plus CIE, CME and CIE, respectively. Moreover, a lower increase was recorded for the control sample.

$\mathrm{pH}$ values increased from 6.60 to 7.0 for control samples (shrimp stored in crushed ice without any additives), while it increased from 6.58 to 6.88 in samples treated with $\mathrm{CME}$ and CIE, and from 6.55 to 6.66 in samples treated with (CIE) plus (CME) (Fig. 1). Similar results were obtained by Özoğul et al. (2011).

The increase of $\mathrm{pH}$ value may have resulted from the proteolysis process, which leads to the increase of free basic amino acids as well as the accumulation of ammonia, amines and other basic products of bacterial breakdown. However, Zeng et al. (2005) noticed that $\mathrm{pH}$ values increase during shrimp samples' cold storage.

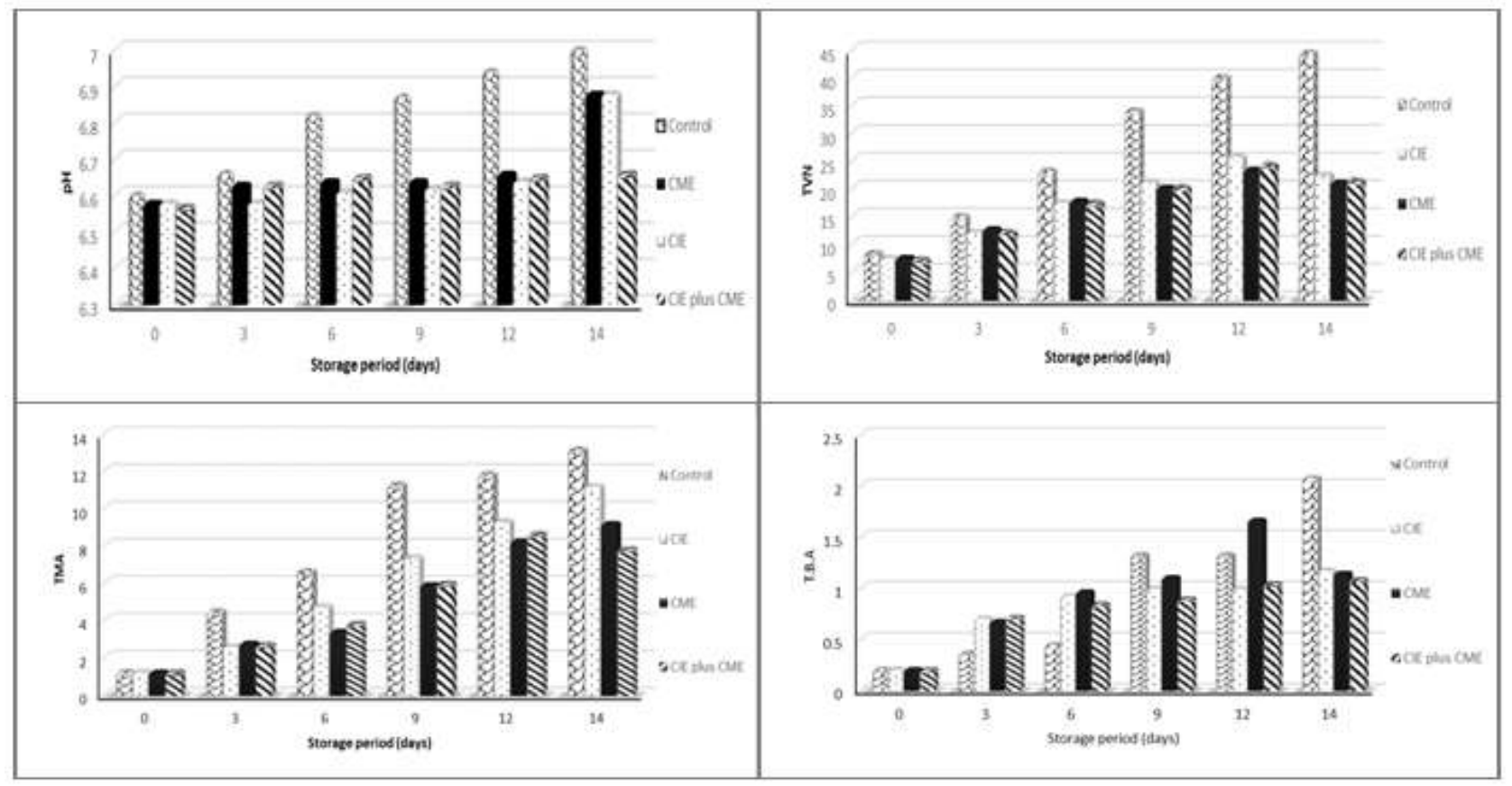

Figure (1): Changes in pH, TVN, TMA and TBA values in peeled shrimp samples during ice storage.

\section{Chemical indices}

The protein contents at zero time were 22.15 , $22.46,22.52$ and $22.38 \%$, whereas, at day 14 of ice storage, the values were decreased to $20.16,21.82$, 21.88 and $21.99 \%$ for control, ice with CIE, CME and their combinations, respectively. These results may be due to increased microorganisms during storage and breakdown of proteins used as nutrients for such microorganisms. Therefore, the breakdown of protein could indicate spoilage of the product. A slight decrease in fat content was observed in all examined shrimp treatments during ice storage (Table 1). These results were similar to the results obtained by Özoğul et al. (2011).

One of the most common methods for studying the freshness degree of meat and fish is TVN. The data presented in Figure (1) showed a gradual increase in total volatile basic nitrogen $\mathrm{mg} / 100 \mathrm{~g}$ in all examined samples' treatments during storage.

There are large variations in the development of TVN among all treatments. As it is shown in Figure
(1), the amounts of TVN at the beginning of the storage period were $8.51,7.60,7.67$ and $7.39 \mathrm{mg} / 100 \mathrm{~g}$, while at day 14 of the storage period, they reached up to $44.60,22.65,21.24$ and $21.59 \mathrm{mg} / 100 \mathrm{~g}$ for control, ice with CIE, ice with CME extract and ice with CME plus CIE extracts respectively. These results are similar to the results presented by Wang et al. (2015), who mentioned that acidic electrolyzed water (AEW) ice was more efficient in inhibiting polyphenol oxidase activity, total bacterial count and TVN formation on raw shrimp when compared with ice from tap water. TVN on day 14, for treatments CME and CIE extract single or combination, was still below the acceptable limit for TVN in shrimps (ranged from 21.24 to 22.65 $\mathrm{mg} / 100 \mathrm{~g}$ ). The acceptable value of TVN of shrimp is $25 \mathrm{mg} \mathrm{N} / 100 \mathrm{~g}$ (Tsironi et al., 2009). This phenomenon may be due to the antimicrobial effect of moringa and soybean extract (Patel and Mohan, 2018).

The results presented in Figure (1) indicated a gradual increase in TMA content in all treatments at the time of storage. As it is shown in the Figure (1), the highest value of TMA (13.21 mg /100g) was obtained 
from shrimp stored in crushed ice without any additives (control), followed by samples stored in ice mixed with CIE (11.23 mg /100g ), shrimp samples stored in ice mixed with CME (9.22 $\mathrm{mg} / 100 \mathrm{~g})$, and finally shrimp samples stored in ice with the CIE plus CME $(7.85 \mathrm{mg}$ $/ 100 \mathrm{~g}$ ) at day 14 of ice storage. The results showed that using CME or CIE in ice improved the quality of peeled shrimp during storage. According to Patel and Mohan (2018), who reported that moringa leaves had an antimicrobial effect, these findings explain treated shrimp samples with CME showed decreased spoilage by microorganisms. The same results were observed in the case of using crude isoflavones. Rani et al. (2018) mentioned that Moringa peregrine was studied for antifungal, antiviral and antibacterial activities. According to Khodanazary (2019), the increase of TMA and TVN compounds might be related to bacterial spoilage that degrades proteins.

The TBA index is widely used as a biochemical quality indicator for assessing lipid oxidation in food. TBA index gives a measure of malonaldehyde formed in the muscle due to the oxidation of lipid peroxides.Data illustrated in Figure (1) showed a gradual increase in Thiobarbituric acid (TBA) value in all treatments under investigation during storage in ice made from water mixed with different additives or control. TBA values of shrimp covered with crushed ice without any additives (control) increased from 0.21 to $2.08 \mathrm{mg}$ malonaldehyde $/ \mathrm{Kg}$ at the last day of storage, while it increased from 0.21 to $1.18,1.15$, and $1.09 \mathrm{mg}$ malonaldehyde $/ \mathrm{Kg}$ in examined shrimp samples stored in ice with CIE, CME extract and ice with CME plus CIE extract respectively.

The values of TBA increased gradually during ice storage; this increase could be attributed to the oxidation of lipids and the formation of some TBAreactive compounds during the storage period. According to Lakshmanan (2000), who reported that TBA value in the range $1-2 \mathrm{mg}$ malonaldehyde $/ \mathrm{kg}$ of fish sample is usually taken as the limit of acceptability. According to Azim et al. (2017), methanol extract of Moringa peregrine showed high DPPH scavenging activity. On the other hand, Yoon and Park (2014) found a significant effect of isoflavones alone on fat decreases in TBARS. In the present study, TBA values were within the acceptable limit during the storage period for all treatments except for the control.

The current study investigated the effect of moringa and isoflavonoids extract addition to ice on free amino acids in shrimp flesh, which could result from protein degradation and decomposition by bacterial proteolytic activity. As shown in Table (2), treated samples resulted in a corresponding decrease in free amino acids concentrations. After 14 days of storage, the minimum values were recorded for CME plus CIE (954.86mg), CME (964.62mg) and CIE (964.87mg). Control samples showed significant increase in free amino acids (1177.56 mg) with maximum values reached after 14 days of storage for arginine, glycine, proline, alanine and histidine compromising $90.41 \%$ (1064.67mg) from the total free amino acids. The rapid spoilage of control samples could be due to its high-water content, high free amino acids, and rapid autolysis by existing enzymes and favor microbial growth conditions, especially with lower content of its connective tissues (Akintola and Bakare, 2013). At the same time, the significant decrease of free amino acids in all treatments compared to control may be due to the antimicrobial effect of additives (moringa and isoflavonoids). The results illustrated in Fig. (1) showed a significant increase in $\mathrm{pH}$ value in the control sample compared to other treatments during storage. The increase of $\mathrm{pH}$ may be due to some bacterial breakdown with free amino acids formation and ammonia. Some plants have antimicrobial properties due to the possession of active compounds such as flavonoids (Tagousop et al., 2018).

Table (2): Free amino acids content $(\mathrm{mg} / 100 \mathrm{~g})$ in shrimp samples during cold storage in ice (Mean \pm S.D)

\begin{tabular}{|c|c|c|c|c|c|}
\hline $\begin{array}{l}\text { Treatments } \\
\text { Acid }\end{array}$ & $\mathbf{X}$ & $\mathbf{A}$ & B & $\mathbf{C}$ & D \\
\hline Aspartic & $2.61^{b} \pm 0.031$ & $5.92^{\mathrm{a}} \pm 0.052$ & $3.29^{b} \pm 0.091$ & $3.26^{b} \pm 0.311$ & $2.99^{b} \pm 0.132$ \\
\hline Lysine & $19.45^{\mathrm{c}} \pm 0.001$ & $28.39^{\mathrm{a}} \pm 0.052$ & $22.86^{\mathrm{b}} \pm 0.007$ & $23.01^{\mathrm{b}} \pm 0.331$ & $21.79^{b} \pm 0.112$ \\
\hline Valine & $16.91^{\mathrm{c}} \pm 0.009$ & $19.85^{\mathrm{a}} \pm 0.002$ & $17.63^{\mathrm{b}} \pm 0.112$ & $17.82^{\mathrm{b}} \pm 0.025$ & $17.66^{\mathrm{b}} \pm 0.131$ \\
\hline Glutamic & $18.19^{c} \pm 0.133$ & $22.16^{\mathrm{a}} \pm 0.019$ & $20.02^{\mathrm{b}} \pm 0.039$ & $19.97^{\mathrm{c}} \pm 0.032$ & $19.35^{\mathrm{c}} \pm 0.001$ \\
\hline Histidine & $71.23^{\mathrm{c}} \pm 0.109$ & $98.52^{\mathrm{a}} \pm 0.111$ & $80.25^{\mathrm{b}} \pm 0.001$ & $79.92^{\mathrm{b}} \pm 0.231$ & $79.01^{b} \pm 0.371$ \\
\hline Glycine & $213.11^{\mathrm{d}} \pm 0.028$ & $281.63^{\mathrm{a}} \pm 0.233$ & $230.92^{b} \pm 0.058$ & $231.08^{\mathrm{b}} \pm 0.231$ & $229.32^{\mathrm{c}} \pm 0.036$ \\
\hline Alanine & $75.25^{\mathrm{d}} \pm 0.001$ & $96.58^{\mathrm{a}} \pm 0.029$ & $79.82^{\mathrm{b}} \pm 0.118$ & $79.71^{\mathrm{b}} \pm 0.192$ & $77.98^{\mathrm{c}} \pm 0.109$ \\
\hline Leucine & $15.92^{\mathrm{d}} \pm 0.007$ & $20.09^{a} \pm 0.132$ & $17.16^{\mathrm{b}} \pm 0.123$ & $17.28^{\mathrm{b}} \pm 0.008$ & $16.74^{\mathrm{c}} \pm 0.123$ \\
\hline Isoleucine & $9.36^{\mathrm{d}} \pm 0.001$ & $16.48^{\mathrm{a}} \pm 0.319$ & $11.24^{\mathrm{b}} \pm 0.142$ & $10.99^{\mathrm{c}} \pm 0.115$ & $10.56^{\mathrm{c}} \pm 0.008$ \\
\hline Proline & $146.20^{\mathrm{d}} \pm 0.021$ & $161.80^{\mathrm{a}} \pm 0.025$ & $150.28^{\mathrm{b}} \pm 0.091$ & $149.57^{\mathrm{c}} \pm 0.002$ & $149.26^{\mathrm{c}} \pm 0.121$ \\
\hline Arginine & $319.22^{\mathrm{d}} \pm 0.005$ & $426.14^{\mathrm{a}} \pm 0.129$ & $331.40^{b} \pm 0.118$ & $332.01^{\mathrm{c}} \pm 0.012$ & $330.20^{\mathrm{c}} \pm 0.312$ \\
\hline Total & 907.45 & 1177.56 & 964.87 & 962.62 & 954.86 \\
\hline
\end{tabular}

$\mathrm{X}$ - Free amino acids content at zero time

A- Control samples after 14 days.

B- Shrimp samples treated with (CIE) after 14 days.

C- Shrimp samples treated with (CME) after 14 days.

D- Shrimp samples treated with (CME+ CIE) after 14 days.

Mean with different letter in the same row indicate significant differences between treatments $(\mathrm{p} \leq 0.05)$. 


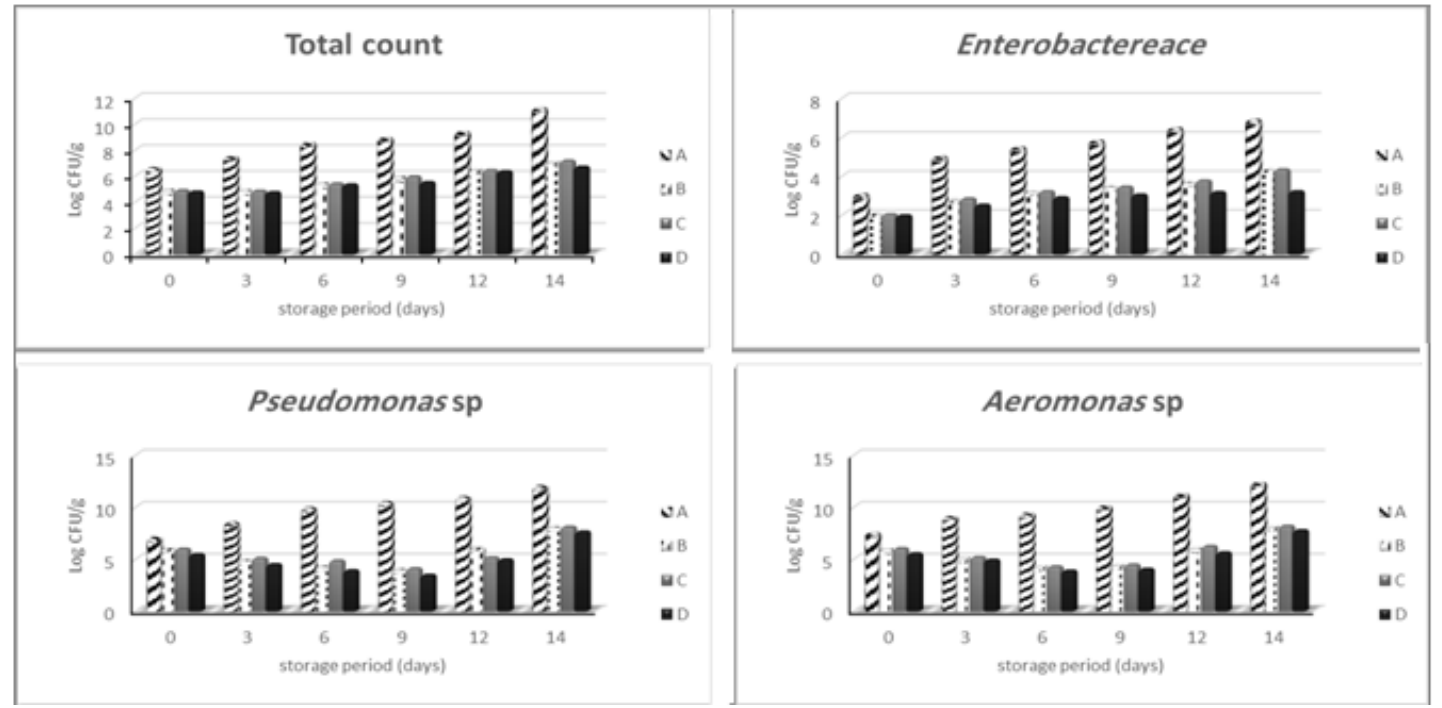

Figure (2): Changes in microbial population of shrimp during ice storage.

\section{Microbiological evaluation}

Shrimp is the most important seafood. Shortage of transportation, storage and processing plant lead to rapid deterioration of shrimp quality. Shrimp is highly perishable and rapidly deteriorates post-mortem, resulting in an obvious off-taste and soft texture (Mastromatteo et al., 2010). The data showed that there was an increase in the total count $(\log \mathrm{CFU} / \mathrm{g})$ with an increase of storage time in all treatments over 14 days of storage when compared with control, while treatments with CME or CIE was believed that it had a greater effect on spoilage microorganisms of peeled shrimp. Treatment with CME plus CIE was the most effective one used on peeled shrimp. Data indicated that the control sample reached the spoilage onset $\left(10^{7}\right.$ $\mathrm{CFU} / \mathrm{g}$ ) after eight days of storage.

On the other hand, the data showed that CME plus CIE additives prolonged the sample's shelf life to 14 days compared to 8 days in the control sample (Fig. 2). Phuvasate and $\mathrm{Su}$ (2010) reported that acidic electrolyzed water having strong antibacterial activities against pathogenic and spoilage bacteria. Shrimp samples coated with ice made from water mixed with CME or CIE and their combinations registered a low bacterial count $\left(10^{4} \mathrm{CFU} / \mathrm{g}\right)$ in all the selective media tested. In contrast, the control sample showed the highest bacterial load $\left(10^{7} \mathrm{CFU} / \mathrm{g}\right)$.

Pseudomonas sp., Aeromonas sp. And Enterobactereace can be inactivated by CME or CIE during the ice storage of shrimp. Patel and Mohan (2018) reported that Moringa peregrina plant parts were identified and reported as antimicrobial, antioxidant, anti-inflammatory and herbicidal. Leaf, seed and extracts of moringa were incorporated as an ingredient in meat products. It is used as an antioxidant and preservative additive without affecting the sensory properties of the final product (Asensi et al., 2017). Dhayakaran et al. (2015) reported that soy isoflavones had antimicrobial activity against Listeria monocytogenes, Pseudomonas aeruginosa and E. coli. Vega-Galvez et al. (2018) found that soy isoflavones microbial activity was against Saccharomyces cerevisiae and Listeria sp.

\section{Sensory evaluation}

Sensory evaluation for control and treated shrimp samples during ice storage for 14 days are presented in Table (3). On days 0, 3, 6, 9, 12 and 14, samples were graded and evaluated by panelists. The control recorded the lowest scores compared to treated samples. At day 9 of the ice storage control sample's score 3.0 (unacceptable) and after 14 days was 1.1 (dislike) while higher scores were obtained from the treated samples as follows 3.5, 3.2 and 3.6 (acceptable) for CME, CIE and CME plus CIE, respectively after 14 days of ice storage. From the previous results, it can be noticed that no significant differences were observed at all samples during storage time between the mean scores of the treatments.

Table (3): Sensory evaluation scores of shrimp treatments during ice storage (Mean \pm S.D)

\begin{tabular}{|c|c|c|c|c|}
\hline $\begin{array}{c}\text { Storage } \\
\text { Days }\end{array}$ & $\mathbf{A}$ & B & $\mathbf{C}$ & D \\
\hline $\mathbf{0}$ & $6.6^{\mathrm{a}} \pm 0.036$ & $6.8^{\mathrm{a}} \pm 0.113$ & $6.8^{\mathrm{a}} \pm 0.122$ & $6.6^{\mathrm{a}} \pm 0.103$ \\
\hline 3 & $4.8^{b} \pm 0.001$ & $5.8^{\mathrm{a}} \pm 0.025$ & $5.6^{\mathrm{a}} \pm 0.190$ & $5.9^{\mathrm{a}} \pm 0.111$ \\
\hline 6 & $4.1^{c} \pm 0.126$ & $5.3^{b} \pm 0.009$ & $5.2^{b} \pm 0.123$ & $5.4^{\mathrm{b}} \pm 0.022$ \\
\hline 9 & $3.0^{\mathrm{b}} \pm 0.121$ & $4.8^{\mathrm{a}} \pm 0.009$ & $4.6^{\mathrm{a}} \pm 0.221$ & $4.8^{\mathrm{a}} \pm 0.007$ \\
\hline 12 & $2.3^{c} \pm 0.101$ & $4.1^{b} \pm 0.129$ & $4.2^{b} \pm 0.001$ & $4.2^{b} \pm 0.016$ \\
\hline 14 & $1.1^{\mathrm{c}} \pm 0.221$ & $3.5^{b} \pm 0.010$ & $3.2^{b} \pm 0.035$ & $3.6^{\mathrm{b}} \pm 0.024$ \\
\hline
\end{tabular}

$\mathrm{A}=$ Control, $\mathrm{B}=\mathrm{CIE}, \mathrm{C}=\mathrm{CME}, \mathrm{D}=\mathrm{CIE}$ plus $\mathrm{CME}$

1: attributes disliked, 3 : attributes unacceptable and 7: attributes most liked

Mean with different letter in the same row indicate significant differences between treatments $(\mathrm{p} \leq 0.05)$. 
On the other hand, significant differences were found between treatments and control during the storage period. At the same time, Asensi et al. (2017) concluded that moringa is incorporated in final meat products' acceptability. These results are agreed with microbiological and chemical parameters.

\section{CONCLUSION}

Crude moringa extract (CME) and crude isoflavones extract (CIE) were most active as natural antioxidants and antibacterial in marine products. These components can delay the chemical changes, retard the microbial growth, maintain the sensory characteristics, and extend shrimp's shelf-life during storage. CIE, CME and plant extracts can be utilized as safe methods for preserving peeled shrimp during storage. Generally, peeled shrimp's shelf life in all treatments was found to be 14 days, compared with eight days in the control sample. Simultaneously, the data showed that no significant differences were observed in all samples during icing storage. From the present study, we need further study to improve the shrimp's storage method to mitigate the loss of the world's food supply.

\section{REFERENCES}

Abdulkadir, A. R., M. M. Hasan and M. S. Jahan (2018). Antimalarial, antioxidant, antimicrobial properties of Moringa Oliefera Lam: A review. Australian Journal of Crop Science, 12(6): 905.

Akintola, S. L. and S. B. Bakare (2013). Effects of Ice Storage on the Biochemical Composition of Macrobrachium vollenhovenii (Herklots, 1857). Journal of Fisheries and Aquatic Science, 8(1): 213-217.

AOAC (2005). Determination of Moisture, Ash, Protein and Fat. Official Method of Analysis of the Association of Analytical Chemists. $18^{\text {th }}$ Edition, AOAC, Washington DC.

Asensi, G. D., A. M. D. Villadiego and R. B. Gaspar (2017). Moringa oleifera: Revisión sobre aplicaciones y usos en alimentos. Archivos Latinoamericanos de Nutrición, 67(2): 86-97.

Azim, S. A. A., M. T. Abdelrahem, M. M. Said and A. Khattab (2017). Protective effect of Moringa peregrina leaves extract on acetaminopheninduced liver toxicity in albino rats. African Journal of Traditional, Complementary and Alternative Medicines, 14(2): 206-216.

Bazemore, R., S. G. Fu, Y. Yoon and D. Marshall (2003). January. Major causes of shrimp spoilage and methods for assessment. In ACS Symposium Series (Vol. 848, pp. 223-234). Washington, DC; American Chemical Society; 1999.

Cervantes-Laurean, D. D. D. Schramm, EL Jacobson, I. Halaweish, G. G. Bruckner and G. A. Boissonneault (2006). Inhibition of advanced glycation end product formation on collagen by rutin and its metabolites. The Journal of nutritional biochemistry, 17(8): 531-540.
Dhayakaran, R. P. A., S. Neethirajan, J. Xue and J. Shi (2015). Characterization of antimicrobial efficacy of soy isoflavones against pathogenic biofilms. LWT-Food Science and Technology, 63(2): 859-865.

Khodanazary, A. (2019). Freshness assessment of shrimp Metapenaeus affinis by quality index method and estimation of its shelf life. International Journal of Food Properties, 22(1): 309-319. DOI: 10.1080/10942912. 2019.1580719

Kuswandi, B., T. S. Larasati, A. Abdullah and L. Y. Heng (2012). Real-time monitoring of shrimp spoilage using on-package sticker sensor based on natural dye of curcumin. Food Analytical Methods, 5(4): 881-889.

Lakshmanan, P. T. (2000). Fish spoilage and quality assessment. In T. S.G. Iyer MK. Kandoran Mary Thomas, PT Mathew (Eds.), Quality Assurance in Seafood Processing (pp. 26-40). Cochin: Society of Fisheries Technologists (India).

Mastromatteo, M., A. Danza, A. Conte, G. Muratore and M. A. Del Nobile (2010). Shelf life of ready to use peeled shrimps as affected by thymol essential oil and modified atmosphere packaging. International Journal of food microbiology, 144(2): 250-256.

Olasupo, A. D., A. B. Aborisade and O. V. Olagoke (2018). Phytochemical analysis and antibacterial activities of spinach leaf. American Journal of Phytomedicine Clinical Therapeutics, (6): 2-8.

Ouraji, H., B. Shabanpour, A. A. Kenari, A. Shabani, S. Nezami, M. Sudagar and S. Faghani (2009). Total lipid, fatty acid composition and lipid oxidation of Indian white shrimp (Fenneropenaeus indicus) fed diets containing different lipid sources. Journal of the Science of Food and Agriculture, 89(6): 993-997. doi.org/10.1002/jsfa.3545.

Özoğul, Y, E. K. Boğa, B. Tokur and F. Özoğul (2011). Changes in biochemical, sensory and microbiological quality indices of common sole (Solea solea) from the Mediterranean Sea, during ice storage. Turkish Journal of Fisheries and Aquatic Sciences, 11(2): 243-251.

Panche, A., A. Diwan and S. Chandra (2016). Flavonoids: An overview. Journal of Nutritional Science, 5, E47. doi:10.1017/jns. 2016.41

Patel, N. and J.S.S. Mohan (2018). Antimicrobial Activity and Phytochemical Analysis of Moringa oleifera Lam. Crude Extracts against Selected Bacterial and Fungal Strains. International Journal of Pharmacognosy and Phytochemical Research, 10(2): 68-79.

Pearson's (1981). Chemical Analysis of Food. Edinburgh London Melbourne and New York.

Phuvasate, S. and Y. C. Su (2010). Effects of electrolyzed oxidizing water and ice treatments on reducing histamine-producing 
bacteria on fish skin and food contact surface. Food control, 21(3): 286-291.

Pietrasik, Z., J. S. Dhanda, R. B. Pegg and P. J. Shand (2005). The effects of marination and cooking regimes on the water binding properties and tenderness of beef and bison top round roasts. Journal of Food Science, 70(2):102-106.

Rajamanickam, K. A. R. T. H. I. C. and S. S. Sudha (2013). In-vitro antimicrobial activity and in vivo toxicity of Moringa oleifera and Allamanda cathartica against multiple drug resistant clinical pathogens. International Journal of Pharma and Bio Sciences, 4(1): 768-75.

Rani, A, N. Zahirah, K. Husain and E. Kumolosasi (2018). Moringa genus: A review of phytochemistry and pharmacology. Frontiers in Pharmacology, 9: 108.

Salvador, P., M. Toldrà, E. Saguer, C. Carretero and D. Parés (2009). Microstructure-function relationships of heat-induced gels of porcine haemoglobin. Food Hydrocolloids, 23(7): 1654-1659.

Tagousop, C. N., S. E. Ekom, D. Ngnokam and L. Voutquenne-Nazabadioko (2018). Antimicrobial activities of flavonoid glycosides from Graptophyllum grandulosum and their mechanism of antibacterial action. BMC complementary and alternative medicine, 18(1): 252-255.

Tsironi, T., E. Dermesonlouoglou, M. Giannakourou and P. Taoukis (2009). Shelf life modelling of frozen shrimp at variable temperature conditions. LWT-Food Science and Technology, 42(2): 664-671. doi.org/10.1016/ j.lwt.2008.07.010

Vega-Gálvez, A., L. Zura, M. Lute, R. Jagus, M. Agüero, A. Pastén and E. Uribe (2018). Evaluación De FibraDietética, Isoflavonas Y Compuestos Fenólicos Con PropiedadesAntioxidantes Y Antimicrobianas De Quinoa \{Chenopodium quinoa Willd\}. Chilean journal of agricultural \& animal sciences, 34(1): 57-67.

Wang, M., J. J. Wang, X. H. Sun, Y. J. Pan and Y. Zhao (2015). Preliminary mechanism of acidic electrolyzed water ice on improving the quality and safety of shrimp. Food chemistry, 176: 333-341.

Yang, X. and K. Qian (2017). Protein OGlcNAcylation: emerging mechanisms and functions. Nature Reviews Molecular Cell Biology, 18(7): 452.

Yoon, G. and S. Park (2014). Antioxidant action of soy isoflavones on oxidative stress and antioxidant enzyme activities in exercised rats. Nutrition research and practice, 8(6): 618-624.

Zeng, Q. Z., K. A. Thorarinsdottir and G. Olafsdottir (2005). Quality changes of shrimp (Pandalus borealis) stored under different cooling conditions. Journal of food science, 70(7): 459-466.

\section{إطالة فترة صلاحية الجمبري المقثر باستخدام المورينجا أوليفيرا و الايزوفلافونات

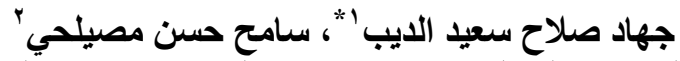

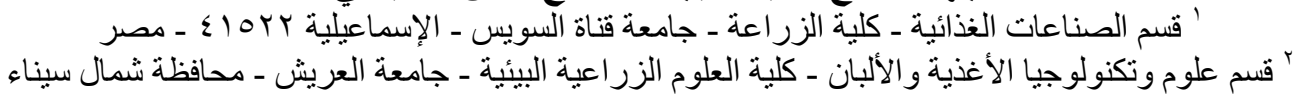

يهدف هذا البحث إلى تقييم فترة صلاحية الجمبرى المقتر المخزن في التلج لمدة ع ا يوم مع استخدام مستخلص الأيزوفلافونات

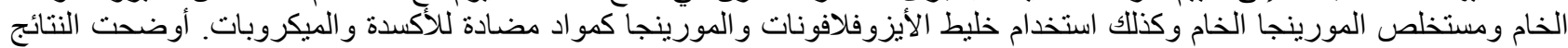

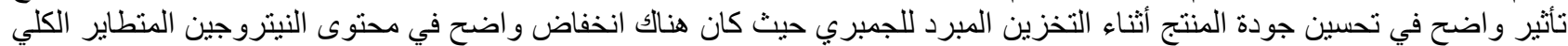

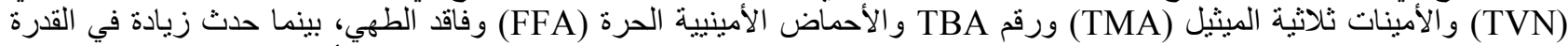

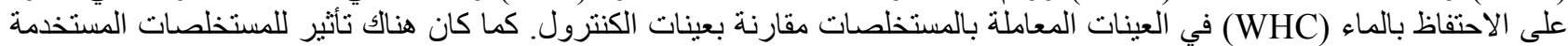

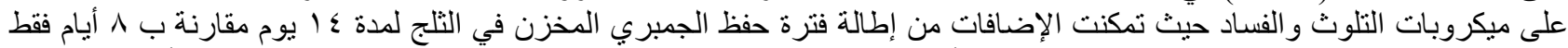

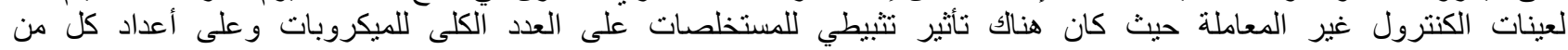
Eseudomonas sp., Aeromonas sp. العينات المعاملة وعينات الكنترول حيث حصلت عينات الكنترول على أقل تقييم حسي بينما حقق خليط مستخلصات الأيزوفلافونات 